\title{
Faktor Risiko Kejadian Asma pada Anak Sekolah Dasar di Kecamatan Wenang Kota Manado
}

\author{
Abraham H. Laisina, D. Takumansang-Sondakh, J. M. Wantania
}

Latar belakang. Asma merupakan salah satu penyebab utama penyakit kronis pada anak. Meningkatnya prevalensi asma menyebabkan para peneliti mengarahkan penelitiannya kepada faktor-faktor risiko timbulnya asma.

Tujuan. Mengetahui hubungan beberapa faktor risiko dengan kejadian asma pada anak Sekolah Dasar (SD) di Kecamatan Wenang, Kota Manado.

Metoda. Penelitian cross sectional, dilakukan pada Mei - Juni 2005 dengan menggunakan kuesioner pada 11 sekolah dasar dengan prosedur pengambilan sampel dua tahap secara acak sederhana.

Hasil. Hasil analisis multivariat dengan uji regresi logistik menunjukkan terdapat hubungan yang bermakna antara riwayat asma pada orang tua, penyakit atopi pada anak selain asma, infeksi saluran napas, dan obesitas dengan kejadian asma pada anak SD di Kecamatan Wenang Kota Manado $(\mathrm{p}<0,001)$.

Kesimpulan. Riwayat asma pada orang tua, penyakit atopi pada anak selain asma, infeksi saluran napas dan obesitas merupakan faktor risiko utama yang berhubungan bermakna dengan kejadian asma pada anak SD di Kecamatan Wenang Kota Manado.

Kata kunci: Asma, faktor risiko, anak sekolah dasar

$2^{\mathrm{s}}$ sma merupakan salah satu penyebab utama penyakit kronis pada anak, ${ }^{1}$ penting bagi keluarga dan masyarakat. ${ }^{2}$ Dalam 20 tahun terakhir telah terjadi peningkatan prevalensi asma pada anak di seluruh dunia, baik di negara maju maupun negara berkembang. Di Aberdeen Inggris, asma pada anak yang didiagnosis oleh dokter meningkat dari 4,1\% pada tahun 1964 menjadi 10,2\% pada tahun 1989 dan $19,6 \%$ pada tahun $1994 .^{3}$ Downs $\mathrm{dkk}^{4}$ pada penelitian

\section{Alamat korespondensi:}

Dr. Abraham H. Laisina, Sp.A

Dr. D. Takumansang-Sondakh, Sp.A(K)

Prof. DR. Dr. J. M. Wantania, Sp.A(K),

Bagian IKA Fakultas Kedokteran UNSRAT/RSU Prof. Dr. R. D. Kandou Manado. di New South Wales, Australia mendapatkan hasil prevalensi asma pada anak sekolah usia 8-11 tahun adalah 38,6\% pada tahun 1997 dengan peningkatan sekitar 8,1\% dibandingkan prevalensi pada tahun 1992 .

Meningkatnya prevalensi asma ini menyebabkan para peneliti mengarahkan penelitiannya pada faktor risiko timbulnya asma. ${ }^{5}$ Faktor genetik dan lingkungan berpengaruh terhadap timbulnya sensitisasi dan telah diketahui sebagai faktor risiko asma dan alergi pada anak. ${ }^{6}$ Identifikasi faktor risiko asma merupakan langkah pertama dalam mengembangkan strategi efektif untuk pencegahan primer asma. ${ }^{7}$ Wantania ${ }^{8}$ telah melakukan penelitian prevalensi asma pada anak SD di Manado, namun sampai saat ini belum ada penelitian tentang faktor risiko yang berhubungan dengan kejadian asma pada anak SD di Manado. Penelitian ini bertujuan untuk mengetahui hubungan 
beberapa faktor risiko dengan kejadian asma pada anak SD di Kecamatan Wenang Kota Manado.

\section{Metoda}

Penelitian ini merupakan studi cross-sectional di Sekolah Dasar di Kecamatan Wenang Kota Manado, dilaksanakan dari bulan Mei - Juni 2005. Subyek penelitian adalah semua murid SD di Kecamatan Wenang Kota Manado yang memenuhi kriteria inklusi: terdaftar pada SD di Kecamatan Wenang Kota Manado tahun ajaran 2004/ 2005, orang tua bersedia mengikuti penelitian dan orang tua yang mengisi kuesioner adalah mereka yang mengetahui benar keadaan anak dalam satu tahun terakhir. Kriteria eksklusi apabila kuesioner tidak dikembalikan oleh orang tua, kuesioner tidak diisi lengkap, dan anak tidak hadir pada saat pengambilan data. Penelitian dengan prosedur pengambilan sampel dua tahap (two stage random sampling), yakni pada tahap I dipilih SD secara acak sederhana dan pada tahap II dipilih anak pada SD terpilih pada tahap I dengan cara acak sederhana.

Variabel tergantung adalah kejadian asma, sedangkan variabel bebas adalah riwayat asma pada orang tua, riwayat penyakit atopi pada orang tua selain asma, penyakit atopi pada anak selain asma, jenis kelamin, penggunaan kasur dan bantal dari kapuk pada waktu tidur, penggunaan karpet, pemilikan hewan peliharaan, orang tua perokok, penggunaan obat nyamuk, jumlah saudara, infeksi saluran napas dan obesitas. Anak menderita asma apabila memenuhi salah satu atau lebih kriteria diagnosis berdasarkan kuesioner sesuai hasil rapat kerja UKK Pulmonologi IDAI, a) Anak pernah menderita asma dan pertama kali mengetahui bahwa anak menderita asma yaitu dari dokter atau petugas kesehatan/mantri/ bidan/perawat/ kader, b) Anak pernah menderita asma dan dalam 6 bulan terakhir anak pernah mendapat serangan asma minimal sebanyak satu kali, c) Anak pernah mengalami sesak napas dan dalam 6 bulan terakhir anak sudah pernah menderita sesak napas minimal satu kali, d) anak pernah mengalami sesak napas disertai gejala lain yaitu waktu bernapas kedengaran bunyi "ngik-ngik", e). Anak pernah napasnya berbunyi "ngik-ngik" dan dalam 6 bulan terakhir pernah minimal 1 kali anak mengalami napas berbunyi "ngik-ngik" dan f) anak pernah menderita napas berbunyi "ngik-ngik" disertai gejala lain yaitu napasnya sesak atau batuk.
Data dianalisis dengan menggunakan uji kaikuadrat, uji mutlak Fisher atau uji Spearman rho untuk analisis bivariat dan uji regresi logistik untuk analisis multivariat. Uji bermakna jika nilai $\mathrm{p}<0,05$.

\section{Hasil}

Dari 43 SD di Kecamatan Wenang Kota Manado, dipilih 11 SD secara acak sederhana dengan jumlah murid 1636 anak. Di antara mereka, 1100 anak memenuhi kriteria subyek dan dari 1100 anak tersebut dipilih 371 anak secara acak sederhana dengan proporsional antara anak yang asma dan bukan asma. Dari 371 anak yang diteliti, 39 anak (10,5\%) menderita asma sedangkan 332 anak (89,5\%) tidak menderita asma. Rerata umur dari sampel yang diteliti adalah 8,9 tahun. Anak laki-laki lebih banyak menderita asma $(11,2 \%)$ daripada anak perempuan (9,7\%) dengan perbandingan $1,15: 1$.

Analisis bivariat menunjukkan terdapat hubungan yang bermakna antara riwayat asma pada orang tua, riwayat penyakit atopi pada orang tua selain asma, penyakit atopi pada anak selain asma, infeksi saluran napas dan obesitas dengan kejadian asma pada anak ( $\mathrm{p}$ $<0,01$ ). Terdapat hubungan bermakna antara pemilikan hewan peliharaan, orang tua perokok dan penggunaan karpet dengan kejadian asma pada anak $(\mathrm{p}<0,05)$. Tidak terdapat hubungan antara jenis kelamin, penggunaan kasur dan bantal dari kapuk pada waktu tidur, penggunaan obat nyamuk dan jumlah saudara dengan kejadian asma ( $p>0,05)$ (Tabel 1 dan 2).

Analisis multivariat dengan uji regresi logistik dengan prosedur stepwise mendapatkan adanya hubungan bermakna antara riwayat asma pada orang tua, penyakit atopi pada anak selain asma, infeksi saluran napas dan obesitas dengan kejadian asma pada anak $(\mathrm{p}<0,001)$ (Tabel 3 dan 4).

\section{Diskusi}

Asma pada anak terutama mengenai anak laki-laki dan hal ini mungkin sebagian disebabkan oleh tingginya prevalensi atopi pada anak laki-laki. Selain itu, saluran napas anak laki-laki cenderung lebih kecil sehingga lebih rentan terhadap obstruksi saluran napas. Sebelum masa puber, asma diderita 1,5 - 3 kali lebih besar pada anak laki-laki. ${ }^{10}$ Wantania ${ }^{8}$ mendapatkan 
Sari Pediatri, Vol. 8, No. 4, Maret 2007

Tabel 1. Distribusi anak berdasarkan faktor risiko dan kejadian asma

\begin{tabular}{|c|c|c|c|c|}
\hline \multirow{2}{*}{ Faktor Risiko } & \multicolumn{2}{|c|}{ Kejadian Asma n\% } & \multirow{2}{*}{ Total } & \multirow[b]{2}{*}{$\mathrm{p}$} \\
\hline & Asma & Bukan Asma & & \\
\hline \multicolumn{5}{|l|}{ Jenis kelamin } \\
\hline Perempuan & $17(9,7)$ & $158(90,3 \%)$ & 175 & \multirow{2}{*}{$0,318^{*}$} \\
\hline Laki-laki & $22(11,2)$ & $174(88,8 \%)$ & 196 & \\
\hline \multicolumn{5}{|c|}{ Riwayat asma pada orang tua } \\
\hline Ada & 16 & 6 & 22 & \multirow{2}{*}{$<0,001^{* *}$} \\
\hline Tidak ada & $23(6,6)$ & $326(93,4 \%)$ & 349 & \\
\hline \multicolumn{5}{|c|}{ Penyakit atopi pada orang tua selain asma } \\
\hline Ada & $31(46)$ & $37(54)$ & 68 & \multirow{2}{*}{$<0,001^{*}$} \\
\hline Tidak ada & $8(2,6)$ & $294(97,4)$ & 303 & \\
\hline \multicolumn{5}{|c|}{ Penyakit atopi pada anak selain asma } \\
\hline Ada & $31 \quad(47)$ & $35 \quad(53)$ & 66 & \multirow{2}{*}{$<0,001^{*}$} \\
\hline Tidak ada & $8(2,6)$ & $297(97,4)$ & 305 & \\
\hline \multicolumn{5}{|c|}{ Kasur dan bantal dari kapuk } \\
\hline Ya & $33(11,5)$ & $255(88,5)$ & 288 & \multirow{2}{*}{$0,134^{*}$} \\
\hline Tidak & $6(7,2)$ & $77(93)$ & 83 & \\
\hline \multicolumn{5}{|l|}{ Penggunaan karpet } \\
\hline Ya & $20(14,4)$ & $119(85,6)$ & 139 & \multirow{2}{*}{$0,030^{*}$} \\
\hline Tidak & $19(8,2)$ & $213(91,8)$ & 232 & \\
\hline \multicolumn{5}{|l|}{ Hewan peliharaan } \\
\hline Ada & $19 \quad(15)$ & $108 \quad(85)$ & 127 & \multirow{2}{*}{$0,022^{*}$} \\
\hline Tidak & $20 \quad(8,2)$ & $224(91,8)$ & 244 & \\
\hline \multicolumn{5}{|l|}{ Orang tua perokok } \\
\hline $\mathrm{Ya}^{\circ}$ & $32(13,1)$ & $213(86,9)$ & 245 & \multirow{2}{*}{$0,013^{*}$} \\
\hline Tidak & $7(5,6)$ & $119(94,4)$ & 126 & \\
\hline \multicolumn{5}{|l|}{ Obat nyamuk } \\
\hline Ya & $38(11,5)$ & $292(88,5)$ & 330 & \multirow{2}{*}{$0,051^{* *}$} \\
\hline Tidak & $1(2)$ & $40(98)$ & 41 & \\
\hline \multicolumn{5}{|l|}{ Infeksi saluran napas } \\
\hline Ya & $31(26,5)$ & $86(73,5)$ & 117 & \multirow{2}{*}{$<0,001^{*}$} \\
\hline Tidak & $8 \quad(3,1)$ & $246(96,6)$ & 254 & \\
\hline \multicolumn{5}{|l|}{ Obesitas } \\
\hline $\mathrm{Ya}$ & 6 & 12 & 18 & \multirow{2}{*}{$0,004^{* *}$} \\
\hline Tidak & $33 \quad(9,3)$ & $320(90,7)$ & 353 & \\
\hline
\end{tabular}

Keterangan : * Uji kai-kuadrat ${ }^{* *}$ Uji mutlak Fisher

Tabel 2. Distribusi anak berdasarkan jumlah saudara dan kejadian asma

\begin{tabular}{ccccc}
\hline \multirow{2}{*}{ Jumlah Saudara } & \multicolumn{2}{c}{ Kejadian Asma n(\%) } & \multirow{2}{*}{ Total } & \multirow{2}{*}{$\boldsymbol{p}$} \\
\cline { 2 - 4 } & Asma & Bukan Asma & & 56 \\
\\
\hline 0 & $10(18)$ & $49(82)$ & 134 & \\
1 & $10(7,5)$ & $124(92,5)$ & 108 & \\
2 & $8(7,4)$ & $100(92,6)$ & 34 & $0,372^{*}$ \\
3 & 8 & 26 & 22 & \\
4 & 2 & 20 & 10 & \\
5 & 0 & 6 & 7 & \\
6 & 1 & $332(89,5 \%)$ & 371 & \\
\hline Total & $39(10,5 \%)$ & & & \\
\hline
\end{tabular}

Keterangan : * Uji Spearman rho 
Sari Pediatri, Vol. 8, No. 4, Maret 2007

Tabel 3. Beberapa faktor risiko yang berhubungan dengan kejadian asma

\begin{tabular}{lcc}
\hline \multicolumn{1}{c}{ Variabel } & Koefisien & Kemaknaan $(\mathbf{p})$ \\
\hline Jenis kelamin & $-0,2053$ & 0,710 \\
Riwayat asma pada orang tua & 4,596 & 0,067 \\
Riwayat penyakit atopi pada orang tua selain asma & 0,9154 & 0,207 \\
Penyakit atopi pada anak selain asma & 2,7793 & 0,001 \\
Penggunaan kasur dan bantal dari kapuk dan atau & & \\
selimut waktu tidur & 0,3057 & 0,664 \\
Penggunaan karpet & 0,9392 & 0,103 \\
Hewan peliharaan & 0,7283 & 0,216 \\
Orang tua perokok & 0,8659 & 0,215 \\
Penggunaan obat nyamuk & 0,509 & 0,702 \\
Jumlah saudara & 0,1564 & 0,490 \\
Infeksi saluran napas & 2,1907 & 0,001 \\
Obesitas & 4,3962 & 0,000 \\
Konstanta & $-8,222$ & 0,000 \\
\hline
\end{tabular}

Tabel 4. Hasil analisis regresi logistik lanjutan untuk beberapa faktor risiko yang bermakna

\begin{tabular}{lcc}
\hline \multicolumn{1}{c}{ Variabel } & Koefisien & Kemaknaan $(\mathbf{p})$ \\
\hline Riwayat asma pada orang tua & 3,0408 & 0,000 \\
Penyakit atopi pada anak selain asma & 3,4580 & 0,000 \\
Infeksi saluran napas & 2,0581 & 0,000 \\
Obesitas & 3,9410 & 0,000 \\
Konstanta & $-5,6608$ & 0,000 \\
\hline
\end{tabular}

perbandingan anak laki-laki dan perempuan yang menderita asma di Palembang sebesar 1,26:1 sedangkan di Manado sebesar 1,11: 1. Penelitian ini mendapatkan anak laki-laki lebih sering menderita asma dari pada anak perempuan dengan perbandingan $1,15: 1$. Namun demikian, perbedaan ini tidak bermakna.

Selama berabad-abad telah diketahui bahwa asma merupakan penyakit yang diturunkan dalam keluarga. ${ }^{11}$ Telah dibuktikan dalam berbagai penelitian bahwa orang tua asma merupakan prediktor yang kuat terhadap kejadian asma pada anaknya. ${ }^{12}$ Hasil penelitian ini menunjukkan bahwa kejadian asma pada anak yang orang tuanya memiliki riwayat asma adalah $72,7 \%$ dan terdapat hubungan antara riwayat asma pada orang tua dengan kejadian asma pada anak ( $\mathrm{p}<0,001)$. Celedon $\mathrm{dkk}^{13}$ mendapatkan kejadian asma sebesar $67,5 \%$ pada anak yang orang tuanya memiliki riwayat asma.

Banyak penelitian membuktikan adanya hubungan bermakna antara riwayat atopi dalam keluarga dengan kejadian asma pada anak. Kusuma dkk ${ }^{14}$ mendapatkan
46,4 \% anak asma mempunyai ayah atau ibu menderita penyakit atopi selain asma, sedangkan Asterina $\mathrm{dkk}^{15}$ mendapatkan 32,9\% anak asma mempunyai riwayat keluarga atopi selain asma. Hasil penelitian ini mendapatkan 45,6\% anak dari orang tua penderita penyakit atopi selain asma menderita asma. Analisis bivariat menunjukkan adanya hubungan antara riwayat penyakit atopi pada orang tua selain asma dan kejadian asma pada anak.

Penderita asma seringkali mempunyai penyakit atopi lain seperti rinitis alergi dan dematitis atopi yang dikatakan sebagai faktor risiko asma. ${ }^{16}$ Penelitian ini mendapatkan $47 \%$ anak dengan penyakit atopi selain asma juga menderita asma. Analisis statistik menunjukkan adanya hubungan bermakna antara penyakit atopi pada anak selain asma dengan kejadian asma.

Tungau debu rumah (TDR) merupakan alergen inhalan penting yang berhubungan dengan timbulnya asma. Populasi TDR paling banyak ditemukan pada kasur dan bantal. ${ }^{17}$ Wickens $\mathrm{dkk}^{18}$ mendapatkan konsentrasi TDR dermatophagoides farinae lebih tinggi 
secara bermakna pada kasur yang terbuat dari kapuk daripada yang terbuat dari busa. Penelitian ini tidak mendapatkan adanya hubungan antara penggunaan kasur dan bantal dari kapuk dengan kejadian asma. Kapuk yang sering dipakai untuk mengisi kasur atau bantal sebetulnya jarang menimbulkan alergi apabila masih baru (berumur kurang dari 1 tahun). Kasur yang lama dan tidak pernah dibersihkan atau dijemur akan menampung TDR dan serpihan kulit manusia yang merupakan makanan TDR. ${ }^{19}$

Seperti kasur dan bantal, karpet juga sering menampung bahan alergenik seperti TDR, serpihan kulit atau bulu binatang. Wickens $\mathrm{dkk}^{18}$ mendapatkan konsentrasi TDR lebih tinggi 10 kali pada ruang tamu yang di dalamnya terdapat karpet. Pada penelitian ini, terdapat hubungan bermakna antara penggunaan karpet di rumah dengan kejadian asma pada analisis bivariat.

Alergi bulu dan serpihan kulit binatang peliharaan seperti kucing dan anjing seringkali menjadi pencetus asma. ${ }^{19}$ Pada penelitian kami, terdapat hubungan bermakna antara pemilikan hewan peliharaan di rumah dengan kejadian asma pada analisis bivariat, tetapi hubungan ini tidak bermakna.

Studi meta analisis yang dilakukan oleh Cook $\mathrm{dkk}^{20}$ menyimpulkan bahwa terdapat hubungan bermakna antara orang tua perokok dengan kejadian asma pada anak. Penelitian kami mendapatkan adanya hubungan bermakna antara orang tua perokok dengan kejadian asma pada anak pada analisis bivariat, tetapi hubungan ini tidak bermakna pada analisis multivariat, sehingga perlu diteliti lebih lanjut.

Obat nyamuk semprot maupun asap obat nyamuk bakar merupakan iritan inhalan yang sering digunakan dan dapat menyebabkan hiperreaktifitas bronkus, namun sejauh mana pengaruhnya terhadap asma masih belum jelas. ${ }^{17,21}$ Pada penelitian ini tidak terdapat hubungan antara penggunaan obat nyamuk dan kejadian asma. Rosalina $\mathrm{dkk}^{21}$ tidak mendapatkan hubungan antara penggunaan obat nyamuk semprot dan kejadian asma. Pada penelitian ini, tidak hanya obat nyamuk semprot dan obat nyamuk bakar dimasukkan dalam analisis tetapi juga obat nyamuk listrik dan oles.

Terdapat data yang mendukung adanya hubungan antara jumlah anggota keluarga atau jumlah saudara dengan kejadian asma. ${ }^{22}$ Posonby $\mathrm{dkk}^{23}$ mendapatkan prevalensi asma menurun secara bermakna dengan meningkatnya jumlah saudara. Penelitian kami tidak mendapatkan hubungan bermakna antara jumlah saudara dengan kejadian asma (Tabel 2). Hasil ini sesuai dengan yang didapatkan oleh Bordner $\mathrm{dkk}^{24} \mathrm{dan}$ Bernsen dkk. ${ }^{25}$

Infeksi saluran pernapasan oleh virus berperan penting terhadap kejadian asma. ${ }^{6,22}$ Ronmark dkk ${ }^{26}$ pada penelitian kohort selama 1 tahun terhadap 3525 anak usia 7 dan 8 tahun mendapatkan adanya hubungan antara infeksi saluran napas dengan kejadian asma. Pada penelitian ini didapatkan hubungan yang sangat bermakna antara adanya infeksi saluran napas dalam 1 tahun terakhir dengan kejadian asma $(\mathrm{p}<0,001)$.

Obesitas di dunia menjadi salah satu faktor risiko asma. ${ }^{27,28}$ Obesitas mempengaruhi asma melalui efek mekanis dan peningkatan respon imun. Juga gen-gen kandidat asma dan obesitas menempati area pada kromosom yang sama yaitu 5q, 6p, 11q dan 12q. Hal ini mendukung hipotesis bahwa dasar kepekaan genetik terhadap asma mungkin sama dengan kepekaan terhadap obesitas. ${ }^{29}$ Pada penelitian ini didapatkan hubungan antara obesitas dengan kejadian asma $(p=0,004)$; sesuai dengan penelitian Schacter $\mathrm{dkk}^{27}$ Gililand dkk ${ }^{28}$ dan Figueroa-Munoz dkk. ${ }^{30}$

Penelitian ini menggunakan kuesioner, diagnosis, dan faktor risiko asma didasarkan pada jawaban yang diberikan oleh orang tua sehingga diperlukan kejujuran orang tua dalam menjawab pertanyaan yang ada dalam kuesioner. Sebagai kesimpulan dapat dikemukakan bahwa adanya riwayat asma pada orang tua, penyakit atopi pada anak selain asma, infeksi saluran napas, dan obesitas merupakan faktor risiko utama yang berhubungan dengan kejadian asma pada anak SD di Kecamatan Wenang, Kota Manado.

\section{Daftar Pustaka}

1. Sly RM. Asthma. Dalam: Behrman RE, Kliegman RM,Jenson HB,eds. Nelson Textbook of Pediatric. Edisi ke-16. Philadelphia : WB Saunders, 2000. h. 664-80.

2. Von Mutius E. The burden of childhood asthma. Arch Dis Child 2000; 82(suppl II):ii2-ii5.

3. Helms PJ, Christie G. Prospects for preventing asthma. Arch Dis Child 1999; 80:401-5.

4. Downs SH, Marks GB, Spork R. Continued increase in the prevalence of asthma and atopy. Arch Dirs Child 2001; 84:20-3.

5. Antova T, Pattenden S, Nikiforov B. Nutrition and respiratory health in children in six central and eastern countries. Thorax 2003; 58:231-6. 
6. Harsoyo. Faktor risiko alergi pada anak. Dalam: Harsoyo, Hapsari, penyunting. Penatalaksanaan alergi dan imunologi pada bayi dan anak masa kini. PIB XV. Semarang: Balai Penerbit Universitas Diponegoro, 2002. h. 1-8.

7. Bailey WC, Clark NM, Gotsch AR. Asthma Prevention Chest; 102 (suppl):216 S-31 S.

8. Wantania JM. Tinjauan hasil penelitian multisenter mengenai prevalensi asma pada anak sekolah dasar di Indonesia. Disampaikan pada Kongres Nasional Ilmu Kesehatan Anak IX Semarang, 13-17 Juli 1993.

9. Musani AI, Pascual RM, Peters SP. Asthma. Dalam: Adelman DC, Casale TB, Corren J, penyunting. Manual of Allergy and Immunology. Edisi ke empat. Philadelphia : Lippincott WW; 2002. h. 93-137.

10. Bogubiewich M, Leung DYM. Asthma Dalam: Hay WW, Hayward AR, Levin MJ, Sondheimer JM, penyunting. Current Pediatric diagnosis and treatment. Edisi ke-15. New York: Lange Medical Books/McGrawHill, 2001. h. 939-48.

11. Hall IP. Genetics and pulmonary medicine : asthma. Thorax 1999; 54:65-9.

12. Litonjua AA, Carey VJ, Burge HA. Parental history and the risk for childhood asthma. Does mother confer more risk than father? Am J Respir Crit Care Med 1998; 158:176-81.

13. Celedon JC, Soto-Quiros ME, Silverman EK. Risk factors for childhood asthma in Costa Rica. Chest 2001; 120:785-90.

14. Kusuma HMSC, Santoso NB, Harriadi, Sumakto, Muid M. Asma anak dan hubungannya dengan atopi pada keluarga. Dalam: Firmansyah A, penyunting. Buku Abstrak Konika XI Jakarta 4 - 7 Juli 1999. IDAI pusat: Jakarta; 1999. h. 645.

15. Asterina R, Siregar SP, Madiyono B, Supriyatno B. Clinical manifestation of childhood asthma persisting until the age of seven. Paediatr Indones 2004; 44:1-6.

16. Ronmark E, Perzanowski M, Platts-Mills T, Lundback B. Different sensitization profile for asthma, rhinitis, and eczema among $7-8$ years old children: report from the obstructive lung disease in northern Sweden studies. Pediatr Allergy Immunol 2003; 14:91-9.

17. Budiman I. Upaya pencegahan asma pada anak. Sari Pediatri 1993; 1:1-9.
18. Wickens K, de Bruyne J, Calvo M. The determinants of dust mite allergen and its relationship to the prevalence of symptoms of asthma in the Asia-Pasific region. Pediatr Allergy Immunol 2004; 15:55-61.

19. Santosa H. Asma bronkial. Dalam: Akib AAP, Matondang CS, penyunting. Buku Ajar Alergi Imunologi Anak, Jakarta: BP IDAI, 1996. h. 179-99.

20. Cook DG, Strachan DP. Health effects of passive smoking. 3. Parental Smoking and prevalence of respiratory symptoms and asthma in school age children. Thorax 1997; 52:1081-94.

21. Rosalina I, Kartasasmita CB, Soepriasi M. Prevalence and risk factors of asthma in children aged 13-14 years. Paediatr Indonesia 1998; 38:265-72.

22. Becker AB. Is primary prevention of asthma possible? Pediatr Pulmonal 2000; 30:63-70.

23. Posonby AL, Couper D, Dwyer T, Carmichael A. Cross sectional study of the relation between sibling number and asthma, hay fever, and eczema. Arch Dis Child 1998; 79: 328-33.

24. Bordner C, Godden D, Seaton A. Family size, childhood infections and atopic disease. Thorax 1998; 53:2832.

25. Bernsen RMD, de Jongste JC, vander Wouden JC. Birth Order and sibship size as independent risk factors for asthma, allergy, and eczema. Pediatr Allergy Immunol 2003; 14:464-9.

26. Ronmark E, Jonsson E, Platts-Mills T, Lundback B. Incidence and remission of asthma in schoolchildren: Report from the obstructive lung disease in northern sweden studies. Didapat dari: http//:www.pediatrics. org/ cgi/content/full/107/ 3/e37.

27. Schachter LM, Salome CM, Peat JK. Obesity is a risk for asthma and wheeze but not airway hyperresponsiveness. Thorax 2001; 56:4-8.

28. Gililand FD, Berhane K, Islam T. Obesity and the risk of the newly diagnosed asthma in school-age children. Am J Epidemiol 2003; 158:406-15.

29. Tantisira KG, Weiss ST. Complex interactions in complex traits: obesity and asthma. Thorax 2001;56(suppl II):ii64-ii74.

30. Figueroa-Munoz JI, Chin S, Rona RJ. Association between obesity and asthma in 4-11 year old children in UK. Thorax 2001; 56:133-7. 